\title{
zona de luz
}

9a्y HORA soy un canto organizado

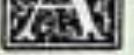

el pecho profundo $\mathrm{y}$ armonioso

que viene desde las primeras mañanas del mundo

con los bolsillos llenos de canciones

y no termino en esta cabeza hirsuta

ni en estos pies que han andado por rulas innumerables mi piel embebe la luz como las hojas mientras mis raices chupan la humedad fresca de la tierra tú que me ves pasar no podrias decir aquel hombre era asi dentro de mi camina el tiempo con sus zapatos embarrados y la vida se filtra como agua lenla a través de terrones hijo del hombre con un andar firme de oso dispuesto al asalto en la atmósfera inmóvil del espiritu ciudad marcho inclinado sobre tu corazón 